\title{
Usaha KPU Mempertahankan Prinsip Transparansi pada Proses Pencalonan melalui Sistem Informasi Pencalonan (SILON)
}

\author{
Ferdana Femiliona ${ }^{1}$
}

\begin{abstract}
Abstrak
Transparansi merupakan salah satu prinsip yang wajib dipenuhi oleh KPU dalam menyelenggarakan pemilu yang berintegritas. Hal ini juga wajib dipenuhi pada proses pencalonan karena merupakan dasar informasi bagi pemilih untuk menentukan pilihannya pada hari pemungutan suara. Untuk melakukan hal tersebut, KPU menggunakan teknologi informasi melalui sistem informasi pencalonan atau silon yang mampu menampilkan data dan dokumen pencalonan secara online kepada pemiih. Tulisan ini membahas tentang penggunaan silon dalam usaha memenuhi transparansi informasi pencalonan kandidat kepada pemilih. Hasil penelitian menunjukan bahwa silon belum mampu memenuhi usaha KPU dalam transparansi informasi. Banyak faktor seperti infrastruktur sistem belum memadahi, peserta pemilu yang enggan melengkapi data dan dokumen di silon, payung hukum yang belum jelas, dan pasifnya KPU sebagai penyelenggara untuk sosialisasi tentang silon kepada pemilih yang membuat masyarakat bahkan tidak tahu keberadaan silon. Hal ini menunjukkan belum adanya akuntabilitas dan kepatuhan hukum dalam prinsip transparansi informasi pencalonan menggunakan silon sehingga gagal dalam memperkuat integritas pemilu.
\end{abstract}

Kata kunci: Transparansi; Pencalonan; Silon; Sistem Informasi

\footnotetext{
1 Mahasiswa Magister Politik dan Pemerintahan, Universitas Gadjah Mada. Email: ferdanafemiliona@mail.ugm.ac.id
} 


\section{PENDAHULUAN}

KPU sebagai EMB (Electoral Management Body) atau penyelenggara pemilu di Indonesia mempunyai wewenang dan fungsi utama yang wajib dilaksanakan. Salah satunya adalah menerima dan memvalidasi pencalonan kandidat (Catt, 2014: 75). Pencalonan kandidat merupakan input awal pemilu (Sukmajati, 2019: 17), dengan peserta pemilu mendaftarkan diri ke penyelenggara pemilu, kemudian berkompetisi dalam pemilu untuk memperebutkan suara dari pemilih. Dengan demikian, pemilih sebagai pemilik kedaulatan wajib mengetahui informasi yang jelas mengenai proses pencalonan dan siapa yang mencalonkan diri. Informasi digunakan sebagai dasar pemilih dalam menentukan pilihan mereka ketika hari pemungutan suara.

Dalam menjamin keterbukaan informasi ini, KPU sebagai EMB menerapkan prinsip transparansi dalam menampilkan proses kandidasi atau pencalonan ke pemilih secara luas. Transparansi EMB ini mengacu pada penyediaan akses ke informasi, menjelaskan alasan pengambilan keputusan berdasarkan informasi, bertindak secara konsisten atau jujur dan dapat diprediksi keberlanjutan informasinya (Pintor, 2012: 16). Informasi yang disajikan adalah informasi yang 
sesuai dengan keadaan sesungguhnya dari proses pencalonan yang berlangsung.

Dalam memfasilitasi transparansi pencalonan kandidat kepada rakyat dalam pemilu, KPU menemui tantangan dalam partisipasi dan hak akses informasi. Hal ini disebabkan karena waktu yang terbatas dan luasnya wilayah Indonesia. Untuk menjawab tantangan itu, pemanfaatan teknologi dan informasi dilakukan sehingga permasalahan partisipasi dan hak akses informasi dari pemilih bisa difasilitasi (Vassil dan Weber, 2011: 1351). Oleh karena itu, teknologi informasi bisa menjangkau seluruh wilayah Indonesia dan rakyatnya dengan berbagai keadaan geografis. Teknologi informasi sangat mempermudah kinerja penyelenggara pemilu dan meningkatkan kepercayaan pemilih atau peserta pemilu terhadap proses pemilu (Perludem, 2019: 18). Hal ini dibarengi dengan peningkatan kapasitas dan kompetensi SDM penyelenggara pemilu dalam hal penggunaan teknologi informasi melalui pelatihanpelatihan dan pendidikan pemilih terkait penggunaan teknologi informasi (Perludem, 2019: 76). Oleh karena itu, teknologi dalam pemilu merupakan hal yang tidak dapat dihindari untuk saat ini (McCormack, 2016).

Teknologi yang dibuat oleh KPU untuk memenuhi prinsip transparansi dalam pencalonan kandidat 
adalah sistem informasi pencalonan atau silon. Silon termasuk teknologi pemilu yang digunakan oleh KPU dalam tahapan pemilu untuk meningkatkan kualitas dan integritas pemilu (Lee dkk, 2017: 107). Silon memfasilitasi pendaftaran dan upload dokumen persyaratan peserta pemilu, baik partai politik maupun kandidat pilkada sesuai dengan jenis pemilihannya. Kemudian, informasi tersebut diolah dan ditampilkan secara online. Hasil dari silon ini dapat dilihat oleh rakyat secara luas melalui portal infopemilu.kpu.go.id. Pemilih dapat dengan mudah melacak siapa calon-calon yang bertarung, apa platform mereka, dan lain lain. Prinsip transparansi yang di idam-idamkan oleh rakyat bisa terpenuhi dengan mudah, bahkan melalui smartphone mereka. Rakyat bisa mengetahui proses pencalonan, ikut berpartisipasi, dan mengambil keputusan dengan benar sesuai hati nurani mereka, setelah mendapatkan banyak informasi mengenai para kandidat yang berlaga dalam pemilu atau pun pilkada.

Dengan latar belakang tersebut, tulisan ini terfokus pada prinsip transparansi yang dilakukan oleh KPU pada tahapan pencalonan dengan menggunakan sistem informasi silon. Tulisan ini mengupas mengenai usaha transparansi yang dilakukan oleh KPU dalam pencalonan menggunakan silon sejak tahun 2017 sampai sekarang. 
Tulisan ini juga mengungkap hambatan-hambatan yang dialami oleh KPU dalam mendorong transparansi proses pencalonan melalui silon dan memberikan rekomendasi untuk peningkatan transparansi dalam pencalonan melalui perbaikan pada sistem informasi pencalonan/ silon.

\section{BEBERAPA SUDUT PANDANG PENGGUNAAN SILON}

Studi mengenai sistem informasi pencalonan sangat sedikit, apalagi yang membahas mengenai transparansi informasi yang dilakukan KPU melalui silon. Dari beberapa literatur review mengenai silon, tulisan ini memilih kajian yang terkait dengan transparansi informasi yang dilakukan KPU menggunakan silon.

Studi transparansi dalam pencalonan menggunakan silon ada dalam penelitian Rahmawati (2019) dengan judul penelitiannya Penerapan Sistem Informasi Partai Politik (Sipol) dan Sistem Informasi Pencalonan (Silon) pada Pemilu 2019 di Indonesia. Metode yang digunakan dalam penelitian tersebut adalah kualitatif deskriptif yang menyoroti upaya KPU dalam mempertahankan transparansi dan akuntabilitasnya dengan menggunakan aplikasi sipol dan silon. Dalam aplikasi silon, KPU 
mengupayakan supaya calon legislatif yang akan mengikuti pemilu wajib mengisikan data lengkap ke silon sehingga profilnya bisa dipublikasikan ke publik. Dengan demikian, rakyat dapat mengakses langsung dan melihat caleg yang akan mereka pilih dalam penyelenggaraan pemilu (Rahmawati, 2019: 12).

Tulisan ini memiliki persamaan dengan penelitian Rahmawati tersebut pada penjelasan mengenai silon dalam mempublikasikan data caleg secara online sehingga masyarakat dapat langsung mengakses informasi tentang caleg dalam pemilu 2019. Perbedaan antara kajian tulisan ini dengan kajian penelitiannya Rahmawati adalah terletak pada usaha yang dilakukan. Penelitian Rahmawati belum membahas mengenai usaha dari KPU dalam menggunakan silon sebagai sarana transparansi pencalonan. Sementara itu, kajian tulisan ini mengkaji tentang usaha KPU dalam penggunaan silon, tidak hanya berhenti pada penampilan informasi.

Penelitian berikutnya dilakukan oleh Noor Ifah dengan judul Verifikasi Persyaratan Administrasi Calon Anggota DPRD Kabupaten Probolinggo dan Sidoarjo pada Pemilu Legislatif Tahun 2014: Studi Kelemahan Verifikasi Persyaratan Administrasi Calon dalam Perspektif Pemilu Berintegritas. Metode yang digunakan adalah kualitatif deskriptif yang menjelaskan 
mengenai verifikasi persyaratan administrasi caleg kabupaten Probolinggo dan Sidoarjo pada pemilu 2014. Dalam menampilkan informasi tentang caleg, KPU menggunakan sistem informasi pencalonan atau silon. Tetapi, informasi yang diunggah masih terkesan formalitas, karena hanya menampilkan CV, menggunakan internet dalam aksesnya, dan tidak disosialisasikan penggunaannya kepada masyarakat, sehingga minim informasi tentang caleg-caleg yang akan bertarung dalam pemilu (Ifah, 2014: 10).

Penelitian yang dilakukan oleh Noor Ifah memiliki kesamaan dengan kajian dalam tulisan ini, yaitu menyoroti mengenai transparansi informasi yang hanya formalitas, yang penting sudah ditampikan dalam website info pemilu. Belum ada usaha dari KPU untuk mensosialisasikan penggunaan silon kepada masyarakat, sehingga masyarakat tidak mengetahui usaha KPU mengenai transparansi informasi pencalonan melalui silon. Perbedaan penelitian Noor Ifah dengan kajian tulisan ini terletak pada pembahasan kenapa usaha transparansi KPU melalui silon ini tidak berhasil. Tulisan ini membahas tentang akuntablitas dan kepatuhan hukum dari transparansi informasi silon dan penelitian Noor ifah tidak membahasnya, tetapi lebih 
fokus verifikasi administrasi caleg di Probolinggo tahun 2014.

\section{WEWENANG DAN FUNGSI UTAMA \\ EMB: MENERIMA DAN MEMVALIDASI PENCALONAN}

KPU sebagai EMB memiliki wewenang dan fungsi utama yaitu (1) menentukan kandidat-kandidat yang layak dipilih; (2) menerima dan memvalidasi pencalonan kandidat (partai politik dan/atau kandidat); (3) melaksanakan pemungutan suara; (4) menghitung suara; dan (5) mentabulasi hasil penghitungan suara (Catt at all, 2014: 75). Dua dari lima wewenang dan fungsi utama KPU membahas tentang kandidasi. Wewenang dan fungsi pertama adalah kandidasi dalam tubuh partai politik, sedangkan yang kedua adalah kandidasi di ranah penyelenggara atau KPU. Kandidasi adalah komponen sentral proses politik dan merupakan input dari proses pemilu, sedangkan kandidat adalah garda terdepan partai politik dalam mengimplementasikan ideologi dan platform partai politik. Dengan demikian, jika kandidasi sebagai bahan mentah pemilu berkualitas jelek, maka pelaksanaan pemilu yang demokratis dan berintegritas tetap tidak mampu melahirkan representasi politik yang sesuai dengan kehendak rakyat (Sukmajati, 2019: 17). 
Oleh karena itu, menerima dan memvalidasi pencalonan kandidat merupakan pintu awal dalam pemilu untuk melahirkan representasi politik dari rakyat sehingga rakyat berhak tahu tentang "kandidasi dalam pemilu" untuk membangun literasi politik dalam rakyat Indonesia dan menghasilkan pemerintahan dan demokrasi yang baik (Suseno, 2013).

\section{TRANSPARANSI DALAM KPU}

Transparansi dalam tata kelola pemilu adalah keterbukaan tentang aturan dan prosedur, hasil dan proses yang digunakan oleh otoritas pemilu serta dianggap untuk membangun kepercayaan publik, meningkatkan martabat pembuat kebijakan dan memfasilitasi akuntabilitas (Norris, 2017: 3). Transparansi pada EMB mengacu langsung pada penyediaan akses ke informasi, bisa menjelaskan alasan untuk pengambilan keputusan pemilih, bertindak secara konsisten, dan dapat diprediksi kelanjutan informasinya (Pintor 2012: 16). Oleh karena itu, transparansi dalam hal operasional kerja merupakan dasar bagi masyarakat yang ingin memeriksa keputusan dan performa KPU. Menerapkan transparansi dapat membantu KPU dalam mengidentifikasi setiap pelanggaran kepemiluan, lemahnya kompetensi dan favoritisme terhadap 
kelompok politik tertentu, serta dapat meningkatkan kredibilitas KPU (Catt et al, 2014: 23). Ketiadaan transparansi dalam proses pemilu dapat meningkatkan kecurigaan publik bahwa sedang terjadi kecurangan dan mengakibatkan kredibilitas pemilu di mata publik rusak. Transparansi menyiratkan bahwa integritas pemilu karena hasilnya benar-benar mencerminkan kehendak rakyat dan semua pemangku kepentingan menerimanya. Akhrinya, transparansi merupakan cara terbaik membangun kepercayaan, didukung upaya lain seperti komunikasi, hubungan masyarakat pro-aktif, dan lain-lain (Pintor, $2012: 16$ ).

Berikut ini beberapa hal yang dapat meningkatkan transparansi EMB (Pintor, $2012: 16$ ):

1. Memberikan informasi publik tentang semua tahapan, kriteria, dan prosedur pemilihan

2. Mengadvokasi partisipasi semua parpol

3. Membuat hubungan dengan masyarakat, media masa, dan organisasi sipil

4. Mempromosikan pendidikan dan informasi pemilih

5. Pendekatan pro-aktif memastikan semua pemangku kepentingan tentang integritas proses 
sebagai bagian dari tanggung jawab kepada parlemen dan publik

Menurut Pipa Norris, transparansi tidak akan memperkuat integritas pemilu jika tidak dilaksanakan dengan akuntabilitas dan mekanisme kepatuhan yang efektif (ditandai dengan adanya hukuman atau penghargaan atas kinerja administratif). Dengan demikian, jika tidak dibarengi dengan akuntabilitas dan kepatuhan, maka transparansi yang ada hanya sebatas formalitas, tidak bisa menyasar kepada masyarakat.

\section{Rantai Integritas Pemilu dari Transparansi, Akuntabilitas dan Kepatuhan}

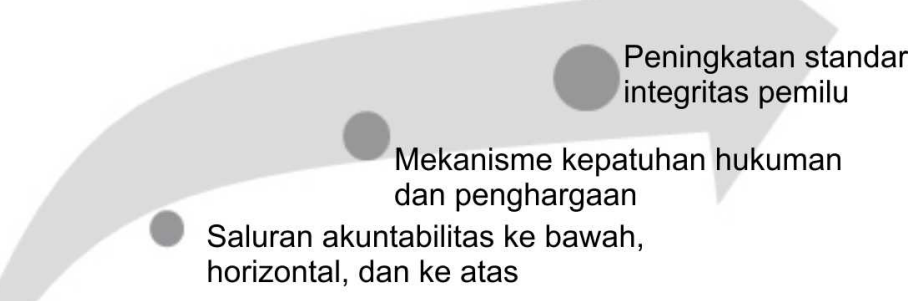

Transparansi dan tata kelola terbuka

Sumber: Norris, 2017: 7

Untuk itu, ketika transparansi dan tata kelola KPU sudah terbuka, maka harus dibarengi dengan 
akuntabilitas ke bawah (kepada rakyat, NGO, dan lainlain), akuntabilitas horizontal (kepada lembaga negara yang lain), dan akuntabilitas ke atas (internasional). Setelah itu, diperlukan kepatuhan hukum yang berlaku sehingga harus mengutamakan peraturan perundangan yang berlaku. Dalam kasus silon ini maka yang harus diutamakan adalah Undang-undang pemilu dan PKPU sebagai peraturan perundangan yang berlaku diranah kepemiluan indonesia. Jika semua tercapai, maka prinsip transparansi mampu meningkatkan standar integritas pemilu (Norris, 2017: 7).

\section{TEKNOLOGI PEMILU DALAM PENCALONAN}

Perludem dan Helena Catt menempatkan teknologi sebagai seperangkat instrumen teknis yang digunakan dalam rangka mencapai tujuan tertentu dari pemilu, seperti efisiensi, efektivitas, hingga menghasilkan proses dan hasil pemilu yang berkualitas juga berintegritas (Perludem, 2019; Catt et.al., 2014). Manfaat dan cara kerja teknologi informasi ini menarik KPU sebagai penyelenggara pemilu untuk menggunakan teknologi dalam pemilu. 
Terdapat tiga kategori teknologi informasi yang digunakan oleh KPU, yaitu (1) teknologi yang digunakan dalam tahapan persiapan pemilu seperti sistem penganggaran dan jaringan dokumen dan informasi hukum pemilu; (2) teknologi yang digunakan dalam tahapan pelaksanaan pemilu, mulai dari sistem informasi daftar pemilih sampai sistem rekapitulasi suara; (3) teknologi yang digunakan pasca pemilu, seperti sistem informasi rencana program strategis penyelenggara pemilu (Perludem, 2019).

Sistem informasi pencalonan atau silon merupakan teknologi pemilu yang dipergunakan sebagai alat bantu dalam transparansi manajemen proses pencalonan, sehingga silon termasuk teknologi yang digunakan dalam tahapan pelaksanaan pemilu, yaitu tahapan pencalonan. Silon merupakan sistem informasi berbasis online yang pertama kali digunakan pada pilkada serentak tahun 2017. Silon dioperasikan tanpa diinstal di komputer, cukup menggunakan browser di komputer yang terkoneksi dengan internet dan login menggunakan username dan password di portal silon yang dikelola oleh KPU RI (Rizkiyansyah dan Silitonga, 2019). Dengan versi online ini calon peserta pemilu (baik partai politik, maupun kandidat calon) dapat melakukan pendaftaran secara online dan mengikuti tahapan yang ada. 
Dalam payung hukumnya, silon merupakan sistem informasi yang membantu KPU, KPU Provinsi/Kab/ Kota, dan pasangan calon dalam melakukan tahapan pencalonan (KPU, 2017, PKPU No. 3 Tahun 2017). Aturan ini menjelaskan bahwa silon lebih digunakan oleh peserta pemilu, seperti paslon Bupati/Walikota, Paslon Gubernur, Paslon Presiden, dan Partai politik untuk membantu manajemen dan publikasi data pencalonan mereka. Payung hukum ini berlaku sampai selesai pemilu 2019, kemudian dilanjutkan dengan mewajibkan penggunaan silon dalam pilkada 2020 tanpa ada campur tangan prosedur manual lagi (KPU, 2019, PKPU No. 18 Tahun 2019). Hasil dari silon tersebut dipublikasikan di infopemilu.kpu.go.id supaya dapat di akses oleh rakyat secara luas.

\section{USAHA TRANSPARANSI INFORMASI PENCALONAN DENGAN TEKNOLOGI INFORMASI}

Tulisan ini menggunakan teori meningkatkan transparansi dari Pintor. Selanjutnya, mengurai bagaimana membuat implementasi transparansi tersebut maksimal sampai meningkatkan integritas pemilu sesuai teori transparansi dari pipa Norris. Karena transparansi tidak akan efektif tanpa dibarengi dengan 
akuntabilitas dan kepatuhan hukum, maka usaha KPU dalam transparansi menggunakan silon akan sia-sia dan sekadar formalitas.

Pada awalnya, KPU membentuk silon untuk melakukan pengecekan batas minimal dan kegandaan dukungan pencalonan pada pilkada serentak 2015 . Kemudian, stakeholder dan NGO terkait merasa perlu adanya transparansi informasi kepada publik mengenai proses pencalonan yang selama ini menjadi ruang rahasia dan gelap bagi rakyat. Rakyat berhak tahu siapa dan bagaimana track-record calon kandidat yang akan mereka pilih saat hari pemungutan suara. Masyarakat sebagai pemegang kedaulatan, perlu didorong untuk mengekpose tahapan kandidasi yang selama ini tidak jelas dan menjadi misteri sehingga dapat terbuka (Gallagher, 1988).

Perwujudan dari transparansi pada tahapan pencalonan tersebut, KPU membuat sistem informasi pencalonan atau silon yang berfungsi secara online. Silon adalah sistem informasi pencalonan yang membantu KPU, KPU Provinsi/Kab/Kota, dan pasangan calon dalam melakukan tahapan pencalonan. Selanjutnya, berdasarkan data silon tersebut, daftar calon kandidat dipublikasikan melalui infopemilu.kpu. 
go.id sehingga mempercepat transparansi dan publikasi data pencalonan kepada masyarakat.

Secara umum, penerapan silon selama ini memiliki kekuatan dan kelemahan. Kekuatan silon bagi KPU adalah memudahkan kinerja penyelenggara pemilu dalam melakukan pendaftaran calon dan verifikasi syarat administrasi kandidat. Selain itu, data silon terpusat di KPU RI sehingga sangat mudah melakukan monitoring dan supervise pada KPU daerah. Dari sisi pemilih, silon membuat pemilih mendapatkan transparansi informasi dengan bisa melihat langsung calon kandidat atau peserta pemilu yang mendaftar KPU beserta semua riwayat hidup, visi-misi, program, partai pengusung, hingga jumlah dukungannya untuk calon perseorangan (Perludem, 2019).

Untuk kepentingan pemilih atau rakyat, transparansi informasi pencalonan tidak pernah dilakukan perubahan pada alamat webistenya. Karenanya, untuk melihat publikasi tahapan pencalonan, masih tetap pada alamat infopemilu.kpu.go.id. Tetapi, untuk pengguna atau user silon pada pemilu tahun 2019, alamat silon berubah silonpemilu.kpu.go.id. Perubahan alamat web tersebut karena mulai masuk ke pencalonan anggota Legislatif DPRD Kabupaten/Kota, berbeda pada tahun 2017 silon yang semula di alamat silon.kpu.go.id yang 
hanya berkutat pada sedikit calon, yaitu calon kepala daerah. Hal ini untuk membedakan antara silon pilkada dengan silon untuk pemilu nasional. Silon untuk pemilu 2019 sudah mengakomodir akun operator DPC partai politik supaya bisa menginput data calegnya sendiri yang kemudian diajukan ke silon KPU Kabupaten/Kota. Pilkada 2020, terjadi kembali perubahan alamat silon pilkada menjadi silon2020.kpu.go.id. Alur yang ada pada pencalonan dan penggunaan silon dalam pilkada tahun 2020 lebih kompleks dibandingkan versi pilkada tahun 2017 dan 2018. Silon KPU Kabupaten/Kota memuat penerimaan berkas file dan data pencalonan dari tiap partai sesuai dengan aturan perundangan seperti keterwakilan perempuan 30\% memengaruhi pengajuan caleg di suatu dapil. Pengecekan kegandaan caleg, penerimaan berkas, dan penolakan berkas juga bisa dilakukan mulai versi ini. Langkah selanjutnya adalah perbaikan tiap tahap dari DCS sampai DCT.

Sampai pilkada 2020, transparansi yang dilakukan melalui silon ini meliputi beberapa hal berikut:

1. Menampilkan semua jenis pemilihan, baik pilkada maupun pemilu nasional 
2. Menampilkan transparansi biodata atau info dari peserta pemilu, mulai dari partai politik sampai para kandidat atau calon

3. Menampilkan grafik rekap pencalonan, seperti keterwakilan perempuan, jumlah paslon berdasarkan umur dan partai

4. Menampilkan semua tahapan yang terjadi dalam proses pencalonan

\section{Transparansi Data Pencalonan dalam Portal Publikasi Silon}

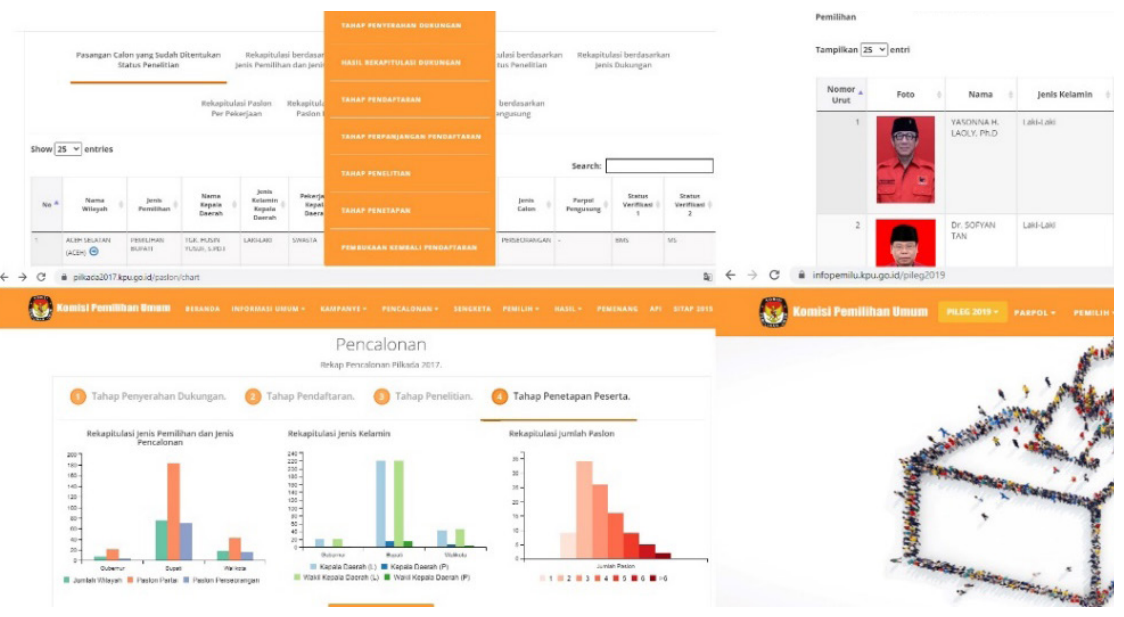

Sumber: infopemilu.kpu.go.id

Permasalahan secara teknis muncul ketika prinsip transparansi menjadi terlalu ruwet dalam menampilkan data pemilu. KPU lebih mengutamakan dalam menampilkan jenis pemilu dan tahunnya terlebih 
dahulu. Hal ini bertujuan supaya pemilih mudah dalam mencari informasi sesuai pemilu atau pilkada yang dipilih. Setelah itu, pemilih akan diberikan pilihan tahapan yang ada dalam pemilu atau pilkada tersebut dan salah satunya adalah pencalonan. Dalam pencalonan ini, informasi diawali dengan tahapan yang banyak dan membingungkan publik. Tidak semua orang paham akan tahapan yang panjang dan berkali-kali diulang dengan form yang juga tidak begitu familiar, seperti tahapan pengajuan paslon, perbaikan pengajuan paslon atau form BB1, BB2, B1, dan sebagainya. Jika transparansi ini juga ditujukan kepada masyarakat awam, harusnya dibuat secara user friendly sehingga masyarakat awam mudah memahami informasi pencalonan, seperti dibuatkan hasil akhir dari pencalonan dengan model grafis yang memuat semua data pencalonan penting sekaligus. Sebagai contoh memuat foto paslon, nama paslon, partai pengusung, nomor urut, dan visi-misi dengan tetap menyertakan link untuk mereka yang ingin mengakses dokumen yang lebih detail (Aji, 2020).

Untuk pengisian data, KPU mendorong secara aktif pada partai politik, kandidat, dan tim sukses untuk melakukan input dan upload data secara mandiri. Hal ini sebagai bagian dari transparansi informasi yang asli tanpa manipulasi karena berasal dari peserta 
pemilu. Kandidat atau peserta pemilu didorong untuk berlomba-lomba memenangkan hati pemilih melalui transparansi data mereka. KPU mendorong dengan cara mengadakan bimtek terkait penggunaan silon dan menjelaskan manfaat transparansi data menggunakan silon. Dengan demikian, silon tidak sekadar alat bantu pengumpulan data dan dokumen, tetapi juga digunakan untuk menyampaikan informasi tentang pencalonan mereka. Dokumen yang ada pada silon adalah dokumen yang sudah divalidasi oleh lembaga terkait sebelum diupload ke silon dan dikonsumsi oleh publik. Hal ini seperti ijazah sekolah yang sudah dikonfrimasikan ke sekolah yang bersangkutan atas keaslian dan validasi dokumen.

Sebetulnya usaha transparansi yang dilakukan oleh KPU melalui silon jika dilihat dari kacamata teknologi sudah lengkap dan detail, tetapi tidak semua pihak bisa menerima atas banyaknya data dan tahapan yang ruwet serta form yang tidak familiar tersebut. Dengan teori dari Pintor, maka usaha transparansi KPU melalui silon sudah memenuhi dua prinsip, yaitu memberikan informasi publik tentang semua tahapan, kriteria, dan prosedur pemilihan dan mengadvokasi partisipasi semua parpol (Pintor, 2012). Dengan teori dari Pipa Norris, maka usaha KPU ini telah memenuhi prinsip pertama, 
yaitu transparansi dan tata kelola terbuka. Namun kenyataannya, pemberian informasi secara transparan dan terbuka harus memperhatikan segmen masyarakat, yang tidak semua orang mempunyai pemahaman mudah dalam mencerna informasi yang terlalu lengkap dan banyak, ada baiknya diberikan dua kanal, yaitu user friendly dan mencakup semua informasi akhir dengan menyertakan link atau menu untuk menuju informasi yang lebih detail sesuai tahapan.

\section{HAMBATAN KETIDAKSIAPAN INFRASTRUKTUR TEKNOLOGI}

Infrastruktur silon dibangun dengan teknologi website secara online. Jadi bisa diakses siapa pun dan di mana pun, dengan menggunakan browser saja. Ini dimaksudkan oleh KPU RI juga sebagai kemudahan dalam transparansi karena tidak perlu melakukan instalasi dan spesifikasi terlalu tinggi. Akan tetapi pada pemilu 2019, kemudahan yang dimaksudkan oleh KPU tidak berjalan dengan mulus. Silon dianggap menambah masalah pada tahapan pencalonan dan menghambat proses pendaftaran akibat sulit diakses secara online (Sukmana, 2018). 
Silon sebenarnya masih berumur sangat muda, baru sekitar 3,5 tahun dariversi online-nya sehingga kelebihan yang ditampilkan terkadang menjadi bumerang. Silon dalam hanya menampilkan data informasi sebagai transparansi, sebenarnya merupakan teknologi yang tidak terlalu berat dalam pengoperasiannya, tetapi memiliki masalah dalam hal penyimpanan dan penampilan data. Tidak seperti sistem informasi daftar pemilih atau Sidalih dari KPU yang mengampu baris data yang sangat banyak sampai ratusan juta data (Cahyaningsih et.al., 2019), tetapi malah mampu menampilkan transparansi data pemilih dengan baik.

Tulisan ini mengurai masalah yang mengganggu transparansi informasi dalam hal infrastruktur, yaitu pemilihan vendor yang kurang tepat dan server dari teknologi informasi. Dalam pengadaan teknologi informasi pemilu, ada tiga tahapan yang harus dipenuhi supaya bisa menjadi tolak ukur legitimasi (Perludem, 2019) yaitu:

\section{Seleksi Vendor}

Seleksi ini harus dilakukan secara transparan dan kompetitif untuk menyeleksi vendor yang memenuhi kualifikasi. 


\section{Penetapan Vendor}

Penetapan adalah pemberian kontrak dengan berbagai perjanjian, seperti teknologi informasi yang diinginkan harus sesuai spesifikasi, kepemilikan teknologi, dan maintenance teknologi informasi.

\section{Pengadaan Teknologi}

Pengadaan teknologi dilakukan dengan anggaran yang tersedia dan dipergunakan sebagaimana mestinya.

Dalam seleksi vendor yang dilakukan KPU RI untuk sistem informasi pencalonan atau silon berbeda dengan vendor untuk sistem lain yang sudah teruji dengan baik seperti sidalih dan situng. Tulisan ini mengungkap bahwa sistem informasi sidalih (daftar pemilih) dan situng (sistem penghitungan suara), berbeda vendor dengan silon, terlihat dari desain dan kemampuan yang berbeda. Server yang terpusat di Jakarta seharusnya lebih memudahkan KPU untuk melakukan pengawasan dan supervise pada data yang ada dalam silon, mengingat jumlah data yang ada tidak sebanyak sidalih atau pun situng. Tetapi kenyataanya, silon lebih parah karena banyak data yang tidak bisa tertampil, bahkan tidak ada 
dokumen yang di-upload ketika akan di-download oleh masyarakat.

Ada indikasi bahwa prinsip transparansi yang dipublikasikan lewat info pemilu dari silon ini masih dianggap kurang penting. Saat pemilu, sorotan masyarakat adalah saat penghitungan suara dan daftar pemilih saja (terdaftar atau tidak dalam DPT) sehingga untuk infrastruktur silon dibuat dengan vendor yang lain atau vendor yang sama tetapi dengan dana yang minim, sehingga hasilnya tidak maksimal.

Dalam hambatan ini, ternyata prinsip akuntabilitas pendukung transparansi, baik ke atas, horizontal, atau pun ke bawah (Norris, 2017) terhambat dengan infrastruktur silon yang belum memadahi. Karenanya, hubungan ke masyarakat, media masa, dan organisasi sipil pun ikut terhambat. Hal ini membuktikan bahwa infrastruktur teknologi selain menghambat transparansi, juga bisa menghambat akuntabilitas dari penyelenggara pemilu yang bisa membuat teknologi ini kehilangan kepercayaan dari masyarakat karena transparansi terhambat. 
HAMBATAN DARI PESERTA PEMILU

YANG ENGGAN MELENGKAPI

DATA (STUDI KASUS KABUPATEN

SUKOHARJO)

Setelah masalah infrastuktur dari silon itu sendiri, masalah berikutnya ada pada sumber daya manusia yang mengoperasikan dan mengisi data pada silon ini untuk keperluan penyelesaian pekerjaan dan transparansi. Masalah tersebut adalah keengganan peserta pemilu dalam melengkapi data pencalonan pada silon. Hal ini disebabkan karena peserta pemilu menganggap silon hanyalah alat bantu dalam melengkapi data pencalonan, bisa diartikan semacam ceklist dan bank data bagi para kandidat dan partai politik. KPU sebagai penyelenggara juga lebih mengutamakan prosedur manual dari pada menggunakan silon jika ternyata partai politik mendapatkan kendala dalam proses pencalonan menggunakan silon. Kendala tersebut seperti partai politik tidak memahami tata cara penggunaan silon ataupun alasan lainnya

Tulisan ini mengangkat kasus di kabupaten Sukoharjo sebagai ilustrasi hambatan dari peserta pemilu dalam usaha transparansi menggunakan silon. Sebab, Sukoharjo merupakan salah kabupaten yang mempunyai tiga hal unik dalam masalah keengganan 
peserta pemilu dalam mengisi data pada silon sehingga layak dijadikan ilustrasi dalam membahas kajian ini. Tiga hal unik ini adalah pertama, kader yang rela diganti jika ia memang tidak memenuhi persyaratan, biasanya seorang kader akan tidak terima terhadap keputusan itu karena sudah mengeluarkan biaya yang cukup banyak dalam pencalonan. Kedua, kader yang dicalonkan tidak merespons perintah partai, sedangkan biasanya seseorang yang sudah mencalonakan diri maka ia akan berusaha sekuat mungkin memenuhi prosedur pencalonan yang ada. Ketiga, pengurus partai yang membuat $100 \%$ calegnya tidak lolos dalam tahap awal pencalonan karena tidak paham tentang prosedur pencalonan menggunakan silon.

Menurut partai Keadilan Sejahtera di Kabupaten Sukoharjo sebagai satu-satunya partai yang langsung lolos ketika tahap pendaftaran bakal calon melalui silon dan pengumpulan berkas hardcopy ke kantor KPU, bahwa koordinasi partai dan kaderisasi yang membuat para caleg atau kandidat ini benar-benar mendorong mereka untuk melengkapi data masingmasing. Kaderisasi membuat seorang caleg sudah lama menjadi anggota parpol sehingga ada loyalitas kepada partainya. Dengan demikian, ketika partai tersebut mengoordinasikan untuk melengkapi berkas, para caleg 
akan berusaha sekuat tenaga melengkapi dokumennya. Jika ternyata tidak bisa melengkapi, caleg tersebut siap sedia jika diganti oleh PKS tanpa ada penolakan (Pratono, 2020).

Partai politik yang bisa melengkapi data-data calegnya tetapi masih ada yang tidak bisa memenuhi kelengkapan dokumen lebih banyak terjadi, seperti partai Gerindra di Sukoharjo. Menurut partai Gerindra di Sukoharjo, ada beberapa anggotanya yang menjadi caleg tetapi tidak bisa melengkapi dokumen dikarenakan caleg tersebut tidak terlalu merespons terhadap perintah partai politik. Padahal, dari partai sudah membentuk tim khusus untuk membantu caleg melengkapi berkas dokumen pencalonannya. Sedangkan alasan caleg tersebut kurang merespons adalah permasalahan pribadi mereka, seperti ada caleg yang tidak melengkapi surat keterangan bebas narkoba karena sedang dalam keadaan sakit dan mengkonsumi berbagai obat. Ada juga yang tidak bisa melengkapi ijazah karena sekolah mereka dahulu sudah tidak ada atau gulung tikar sehingga saat kehilangan ijazah atau mau legalisir sudah tidak bisa dilakukan (Sari, 2020).

Untuk partai yang 100\% tidak bisa memenuhi data pencalonan pada awal pendaftaran di Kabupaten Sukoharjo adalah partai Golkar. Sebagai partai yang 
sudah lama sekali di Indonesia, ternyata permasalahan sampai $100 \%$ tidak bisa memenuhi data pencalonan karena terjadi salah pemahaman atas informasi dari KPU. Karenanya, seluruh caleg partai golkar mengirimkan data ke silon adalah fotocopy legalisir. Padahal, untuk di-upload di silon adalah berkas asli seperti ijazah, SKCK, dan surat dari pengadilan. Berkas fotocopy legalisir adalah berkas hardcopy yang dikirim ke KPU. Kesalahan tersebut dengan sigap diperbaiki oleh partai Golkar sehingga tetap lolos pada tahap perbaikan (Purwadi, 2020).

Dari beberapa penjelasan tersebut, bisa disimpulkan bahwa yang mendorong partai politik dan kandidat atau caleg melengkapi data dokumen yang akan diupload ke silon adalah perintah koordinasi partai yang jelas, kemudian kaderisasi anggota partai yang loyal kepada partai. Sedangkan partai politik yang kesulitan melengkapi data pada silon mengalami berbagai hambatan seperti permasalahan pribadi yang menghambat kandidat dan caleg tidak bisa memenuhi kelengkapan dokumen, salah pemahaman inforamasi dari partai atau pun dari KPU.

Konsekuensi bagipartai politikyang tidak melengkapi data pada silon tersebut hampir tidak ada. Mereka hanya menerima akibat dari pekerjaan mereka sendiri, 
yaitu tidak tampilnya informasi mengenai pencalonan dari kandidat mereka sendiri di silon. Tetapi, hal ini juga disanggah oleh beberapa partai politik bahwa apa yang tampil di info pemilu sebagai hasil dari silon tidak menimbulkan dampak apa pun, karena jarang sekali masyarakat yang mengakses ke sana. Masih tetap lebih efektif menampilkan transparansi proses pencalonan mereka melalui alat peraga kampanye secara fisik yang ditempel di tempat-tempat tertentu.

\section{USAHA TRANSPARANSI SILON DARI KACAMATA PAYUNG HUKUM}

Dalam Undang-undang Pemilu No. 7 Tahun 2017 tentang Pemilihan Umum maupun Undang-undang No. 10 Tahun 2016 pengganti kedua Undang-undang No. 1 Tahun 2015 tentang Pemilihan Gubernur, Bupati, dan Walikota, tidak disebutkan bahwa tahapan pencalonan menggunakan teknologi informasi untuk membantu penyelenggaraan proses dan transparansi data ke masyarakat. Karenanya, KPU membuat peraturan KPU (PKPU) untuk melegalkan penggunaan teknologi informasi pencalonan atau silon dalam tahapan pencalonan ini. Untuk pilkada 2017 sampai pemilu 2019, payung hukum penggunaan silon ada pada PKPU No. 3 
Tahun 2017 Pasal 97 yang membolehkan penggunaan silon pada tahapan pencalonan.

"Untuk memudahkan pelaksanaan proses pencalonan sejak masa penyerahan dokumen dukungan Pasangan Calon perseorangan sampai dengan penetapan Pasangan Calon peserta Pemilihan, KPU Provinsi/KIP Aceh, dan KPU/KIP Kabupaten/Kota dapat memanfaatkan sarana teknologi."

Pada pilkada serentak tahun 2020, KPU membuat payung hukum untuk silon pada PKPU No. 18 Tahun 2019 Pasal 97 yang intinya mewajibkan pemakaian silon dalam proses pencalonan pilkada, hal ini merupakan pertama kalinya silon wajib dipakai dan mengabaikan proses manual dalam pencalonan.

"KPU Provinsi/KIP Aceh dan KPU/KIP Kabupaten/ Kota wajib menggunakan sistem informasi pencalonan dan memanfaatkan sarana dan prasarana teknologi yang dikembangkan oleh KPU untuk memudahkan pelaksanaan proses pencalonan sejak masa penyerahan dokumen dukungan pasangan calon perseorangan sampai dengan penetapan pasangan calon peserta pemilihan."

Pada payung hukum PKPU No. 3 Tahun 2017, silon masih belum diwajibkan namun dapat dimanfaatkan untuk mendukung pencalonan. Hal ini membuat payung hukum masih kurang mendukung prinsip transparansi 
karena tidak ada kewajiban dalam pengisian data informasi di silon. Tetapi, KPU memperbaikinya pada payung hukum yang paling akhir, PKPU No. 18 Tahun 2019. Silon berpotensi menjadi teknologi informasi yang benar-benar siap dalam memberikan transparansi informasi mengenai proses pencalonan kepada rakyat. Hal ini disebabkan karena silon sudah diwajibkan dalam penggunaanya sehingga bisa memaksa kandidat atau peserta pemilu untuk mengisi dan melengkapi data dalam silon. Lengkapnya data pencalonan dalam silon akan berpengaruh pada formulir-formulir pencalonan yang dikeluarkan oleh silon. Formulir ini akan ditandatangani dan dipergunakan sebagai dokumen resmi pendaftaran calon.

Akantetapipada praktiknya,kewajiban menggunakan silon tidak bisa dipaksakan kepada peserta pemilu. Hal ini dikarenakan KPU membuat payung hukum penggunaan silon dalam PKPU, tetapi tanpa ada dasar penggunaanya dalam undang-undang pemilu (Purwadi, 2020). Jika dipaksakan, maka akan terjadi penolakan dari peserta pemilu, yang berimbas data di silon menjadi tidak terisi, Usaha transparansi pun akan terhambat karena kekosongan dan ketidaklengkapan data. Dalam hal ini, mekanisme kepatuhan pada hukum menjadi tidak terpenuhi karena PKPU yang dijadikan dasar 
hukum silon tidak memiliki dasar kuat karena tidak diatur dalam Undang-undang. Prinsip transparansi tidak akan bisa meningkatkan integritas pemilu karena kepatuhan pada hukum tidak terpenuhi (Norris, 2017).

\section{HAMBATAN DARI KPU SEBAGAI PENYELENGGARA}

Penggunaan silon pemilu 2019 masih belum totalitas karena proses pencalonan masih mengutamakan penggunaan form manual. Jika form hasil dari input data menggunakan silon mengalami gangguan teknis, seperti server down atau terkena serangan hacker, maka penggunaan silon akan diabaikan dan lebih memilih form manual yang dicetak menggunakan printer. Form manual tetap menjadi hal yang utama dan legal bagi KPU dalam menerima formulir pencalonan. Hal ini merupakan efek dari PKPU No. 3 Tahun 2017 yang belum mewajibkan penggunaan silon.

Infopemilu.kpu.go.id atau halaman publik silon sudah menampilkan detail paslon yang dicalonkan. Hal yang ditampilkan mulai dari foto calon, CV, visi-misi, dan semua file berkas pencalonan ditampilkan. Hanya saja, banyak kendala terkait foto tidak tampil dan kosongnya file pencalonan, hal ini menandakan kurang 
tertibnya administrasi baik cari pihak calon maupun KPU yang melakukan pengecekan. Semua terkesan menggunakan silon masih setengah-setengah, antara penting dan tidak. Hal ini bisa memengaruhi prinsip transparansi yang disampaikan oleh KPU pada proses pencalonan karena tidak ada ketersediaan data. Hal ini berdampak cukup signifikan karena pemilh masih banyak yang bingung atas kandidat yang mereka pilih saat pemilu 2019.

Selain melegalkan form manual dan tidak melakukan cek ulang data yang tertampil di silon, masalah dari penyelenggara terkait transparansi yang dihadapi silon adalah masalah publikasinya. Pihak KPU sebagai penyelenggara tidak pernah menyosialisasikan atau mengampanyekan tentang infopemilu.kpu.go.id sebagai garda terdepan transparansi informasi pemilu, terutama untuk pencalonan. Semua masih lebih mengandalkan bentuk fisik, seperti APK baliho, spanduk, leaflet, dan sebagainya. Hal tersebut mengurangi prinsip transparansi dalam pencalonan yang seharusnya pemilih mendapatkan informasi akan di mana bisa mendapatkan informasi dan mendapatkan isi lengkap dari informasi tersebut.

Hal terakhir dari pembahasan ini adalah sosialisasi yang dilakukan oleh KPU dan peserta pemilu (partai 
politik dan kandidat) mengenai keberadaan silon (melalui info pemilu). Usaha transparansi proses pencalonan akan sia-sia jika masyarakat luas tidak mengetahui bahwa ada suatu sistem informasi yang menampilkan data dan dokumen kandidat atau peserta pemilu secara transparan dan online. Efek dari PKPU No. 3 Tahun 2017 yang belum mewajibkan penggunaan silon ini berakibat tidak ada rasa kewajiban KPU dan peserta pemilu untuk menyosialisasikan silon sebagai garda terdepan informasi pencalonan.

Efek selanjutnya adalah minimnya publikasi data dan dokumen oleh para kandidat dan peserta pemilu, seperti sudah dibahas pada bab sebelumnya. Efek minim publikasi ini adalah respons dari minimnya sosialisasi dari silon sehingga merasa tidak terlalu penting dan wajib untuk meng-upload data dan dokumen ke silon. Efek terakhir adalah minimnya transparansi data dan dokumen sebagai bukti adanya proses pencalonan kepada masyarakat luas. Baik KPU maupun peserta pemilu lebih suka menggunakan APK atau alat peraga kampanye secara fisik yang ditempel di tempat-tempat strategis. Padahal dengan adanya media sosial, sharing data dan dokumen dari silon akan sangat mudah dan lebih menjangaku masyarakat secara luas. 
Oleh karena itu, bisa disimpulkan bahwa KPU sebagai penyelenggara tidak berhasil dalam memenuhi prinsip transparansi EMB dari Pintor, yaitu membuat hubungan dengan masyarakat, media masa, dan organisasi sipil serta mempromosikan pendidikan dan informasi pemilih (Pintor, 2012). Demikian pula, KPU sebagai penyelenggara tidak bisa menampilkan saluran akuntabilitas ke bawah atau kepada masyarakat dan pemilih (Norris, 2017). Dengan demikian, segala usaha transparansi dari sisi teknologi yang dibuat silon ini menjadi sia-sia karena tidak akan sampai pada masyarakat luas tanpa adanya akuntablitas ke bawah, seperti membuat hubungan ke masyarakat, media masa, dan lain-lain dalam bentuk pendidikan informasi pencalonan.

\section{KESIMPULAN}

KPU sudah memulai menerapkan prinsiptransparansi dalam proses pencalonan kandidat sejak 2017, yaitu dengan menggunakan sistem informasi pencalonan atau silon. Dari sisi teknologi, sistem informasi sudah sangat lengkap sebagai sistem yang bisa menampilkan data pencalonan secara lengkap, mulai dari pemilu yang berlangsung, tahapan yang ada dalam pencalonan, sampai data dan dokumen yang terkait dengan peserta 
pemilu dan kandidat secara detail. KPU juga sudah mengubah payung hukumnya dari menjadi alat bantu menjadi alat yang wajib digunakan dalam pencalonan sehingga tidak ada lagi pilihan menggunakan cara manual dalam proses dan formulir pencalonan.

Namun demikian, perihal di atas tetap tidak cukup dalam usaha KPU untuk memenuhi prinsip transparansi. Dari teori Pintor dan Pipa Norris didapatkan kesimpulan sebagai berikut:

1. Infrastruktur silon belum memadahi dalam hal server yang digunakan dalam menyimpan software dan data dari silon sehingga hal yang sudah dilakukan dan sesuai dengan teori dari Pintor, seperti memberikan informasi publik tentang semua tahapan, prosedur serta mengadvokasi partai politik (Pintor, 2012) dalam pengisiannya menjadi terhambat sehingga transparansi dan tata kelola terbuka sesuai juga terhambat (Norris, 2017).

2. Peserta pemilu yang enggan melengkapi data di silon dan payung hukum yang belum jelas, membuat pendekatan pro-aktif pemangku kepentingan (Pintor, 2012) yang terkait dengan silon, yaitu peserta pemilu, kandidat, dan partai 
politik menjadi terhambat. Kepatuhan terhadap hukum (Norris, 2017) juga tidak terjadi karena pembuatan PKPU yang menjadi dasar silon ternyata tidak diatur dalam Undang-undang. Ini membuat payung hukum silon tidak kuat dan akhirnya berkaitan dengan mengapa peserta pemilu enggan melengkapi data di silon.

3. Pasifnya KPU sebagai penyelenggara untuk memberikan sosialisasi tentang penggunaan silon kepada masyarakat dalam rangka usaha transparansi informasi pencalonan. Ketiadaan usaha dari KPU ini tidak sesuai dengan hubungan dengan masyarakat, media massa, dan organisasi sipil serta mempromosikan pendidikan dan informasi pemilih (Pinto, 2012). Hal ini dikarenakan saluran akuntabilitas dari KPU ke bawah (Norris, 2017) tidak ada sama sekali dan akhirnya berimbas pada usaha transparansi yang tidak sampai pada sasaran atau hanya formalitas.

Dari paparan di atas bisa disimpulkan bahwa usaha transparansi KPU melalui silon ini belum menunjukkan akuntabilitas dan kepatuhan hukum. Usaha transparansi masih sebatas memenuhi syarat transparansi publik, tetapi belum ada usaha dari KPU supaya transparansi 
informasi pencalonan ini sampai kepada masyarakat dan meningkatkan integritas pemilu.

\section{SARAN}

Supaya usaha transparansi KPU dalam hal informasi pencalonan menggunakan silon bisa maksimal dan meningkatkan integritas pemilu, maka berikut ini adalah saran-saran untuk penelitian sejenis selanjutnya.

1. Dalam transparansi dan tata kelola terbuka, ada baiknyainformasipada silon dibuatuserfriendly, mudah dicerna tetapi memuat keseluruhan informasi yang dicari oleh masyarakat dengan tetap menyertakan link detail yang bisa menampilkan semua data lengkap dan semua tahapan.

2. Meningkatkan akuntabilitas baik ke atas, kebawah, dan horizontal. Dalam kajian ini belum menemukan akuntabilitas silon mengarah ke atas atau internasional. Ada baiknya silon mempunyai fasilitas bahasa Inggris supaya bisa diakses oleh lembaga-lembaga demokrasi atau pengguna dari negara lain. Akuntabilitas horizontal juga belum penulis temukan di mana KPU belum ada usaha menjalin kerja sama 
dengan lembaga negara lain terkait silon ini. Sedangkan akuntabilitas ke bawah, KPU harus menyosialisaikan penggunaan silon kepada pemilih sebagai salah satu alat sosialisasi pencalonan. Hal ini dimaksudkan supaya pemilih benar-benar mendapatkan informasi dari silon, bukan dari tempat lain.

3. Kepatuhan hukuman dan penghargaan juga harus diperhatikan ketika penyusunan payung hukum tentang silon ini, ada baiknya silon juga diatur dalam Undang-undang supaya PKPU yang mengatur penggunaan silon punya dasar kuat dan bisa memaksa peserta pemilu untuk menggunakannya. 


\section{REFERENSI}

Biro Teknis dan Hupmas KPU RI. (2019, 11 19-24). Pentingnya Sistem Informasi Pencalonan (Silon) dalam Proses Pencalonan Pemilihan Tahun 2020-Bimbingan Teknis Penggunaan Aplikasi Sistem Informasi Pencalonan Pemilihan Tahun 2020. Kabiro, Performer. Jakarta, Indonesia.

Cahyaningsih, Agustina, Hendar Wijayadi, RyanKautsar. (2019). Penetrasi Teknologi Informasi dalam Pemilihan Kepala Daerah Serentak 2018. Yogyakarta: Polgov UGM.

Catt, Helena, Andrew Ellis, Michael Maley, Alan Wall, dan Peter Wofl. (2014). Electoral Management Design. Stockholm: International IDEA.

Gallagher, Michael dan Michael Marsh (eds). (1988). Candidate Selection in Comparative Perspective: The Secret Garden of Politics. London: Sage.

KPU. (2019). Peraturan Komisi Pemilihan Umum No. 1 Tahun 2020 tentang Perubahan Ketiga PKPU No. 3. Tahun 2017 tentang Pencalonan Kepala Daerah, Gubernur, Bupati, dan Walikota. Jakarta: Komisi Pemilihan Umum. 
KPU. (2019). Peraturan Komisi Pemilihan Umum No. 3 Tahun 2017 tentang Pencalonan Kepala Daerah, Gubernur, Bupati, dan Walikota. Jakarta: Komisi Pemilihan Umum

KPU. (2019). Peraturan Komisi Pemilihan Umum No. 18 Tahun 2019 tentang Perubahan Kedua PKPU No. 3 Tahun 2017 tentang Pencalonan Kepala Daerah, Gubernur, Bupati, dan Walikota. Jakarta: Komisi Pemilihan Umum.

Lee, Antony, dkk. (2017). Inovasi Pemilu: Mengatasi Tantangan, Memanfaatkan Peluang. Jakarta: KPU.

McCormak, Conny. (2016). Democracy Rebooted: The Future of Technology in Elections. Washington: Atlantic Council.

Norris, Pippa. (2017). Election Watchdogs: Transparency, Accountability and Integrity. New York: Oxford University Press.

Perludem. (2019). Panduan Penerapan Teknologi Pungut Hitung di Pemilu. Jakarta: Perludem.

Pintor, Lopez, Rafael. (2012). Principles for Independent and Sustainable Electoral Management: Global Comparative Experiences. Cairo: UNDP. 
Rizkiyansyah, K.F. dan Silitonga, M. B. (2019). Manajemen Penyelenggara pemilu dalam Tanthowi, P., Aditya, P., Sukmajati, M. (Ed). (2019). Tata Kelola Pemilu di Indonesia. Jakarta: KPU RI.

Sukmana, Yoga. (2018). Silon Sempat Bermasalah, KPU Balik Salahkan Kebiasaan Parpol. Kompas. com. Diakses dari https://nasional.kompas.com/ read/2018/07/17/ 13461671/silon-sempat-bermasalahkpu-balik-salahkan-kebiasaan-parpol.

Sukmajati, Mada. (2019). Kandidasi dalam Partai Politik di Indonesia. Yogyakarta: Polgov Fisipol UGM.

Suseno, Nuri. (2013). Representasi Politik: Perkembangan dari Ajektiva ke Teori. Depok: Puskapol FISIP UI.

Vassil, K. \& T. Weber. (2011). A Bottleneck Model of E-Voting: Why Technology Fails to Boost Turnout. New Media \& Society, 13 (8), 1336-1354. 
WAWANCARA

Wawancara dengan Anggota KPU Sukoharjo periode 20132018, Mulat Bayu Aji, SE, MH pada tanggal 30 mei 2020

Wawancara dengan LO PKS kabupaten Sukoharjo, Pratono pada tanggal 28 mei 2020

Wawancara dengan LO Partai Golkar kabupaten Sukoharjo, Purwadi pada tanggal 28 mei 2020

Wawancara dengan LO Partai Gerindra kabupaten Sukoharjo, Sari pada 28 mei 2020 
